ілюстративного навчального матеріалу є одним 3 шляхів підвищення ефективності та якості навчання.

\title{
Література:
}

1. Теорія та практика змішаного навчання : монографія / В.М. Кухаренко, С. М. Березенська, К.Л. Бугайчук та ін.; за ред. В.М. Кухаренка - Харків: «Міськдрук», НТУ «ХПІ», 2016. - 284 с.

2. Досвід переживання пандемії covid-19: дистанційні психологічні дослідження, дистанційна психологічна підтримка: матеріали онлайнсемінарів (23 квітня та 15 травня 2020 р., Київ). Київ, 2020. 121 с.

3. Дистанційне навчання як сучасна освітня технологія: матеріали міжвузівського вебінару (31 березня 2017 р., м. Вінниця). Вінниця, 2017. $102 \mathrm{c}$.

DOI https://doi.org/10.30525/978-9934-26-041-4-88

\section{ПІДГОТОВКА МАЙБУТНІХ ВИХОВАТЕЛІВ З ПРАВОМ ВИКЛАДАННЯ АНГЛІЙСЬКОЇ МОВИ ДО РЕАЛІЗАЦІЇ ПЕДАГОГІЧНОГО СПІЛКУВАННЯ У РОБОТІ 3 ДОШКІЛЬНИКАМИ}

\author{
Гуманкова О. С. \\ кандидат педагогічних наук, \\ доиент кафедри англійської мови з методиками викладання \\ в дошкільній та початковій освіті \\ Житомирський державний університет імені Івана Франка \\ Михайлова О. С. \\ кандидат педагогічних наук, \\ дочент кафедри англійської мови з методиками викладання \\ в дошкільній та початковій освіті \\ Житомирський державний університет імені Івана Франка \\ м. Житомир, Украӥна
}

Процеси інтеграції української мовної освіти у європейський освітній простір актуалізують проблему ранньої іншомовної освіти та підвищують вимоги до професійної підготовки вихователів, які здійснюють навчання іноземної мови дітей дошкільного віку. 
Важливість цілеспрямованої підготовки вихователів до реалізації педагогічного спілкування на заняттях 3 англійської мови (AМ) зумовлена детермінованістю методу комунікативної взаємодії в процесі організації іншомовної освіти.

Аспекти підготовки майбутніх вихователів до здійснення англомовного педагогічного спілкування розкрито у наукових доробках: С. Будака, О. Лободи, I. Мордоус, Т. Марчій-Дмитраш, Л. Петько, Т. Шкваріної, А. Сдвардса, Р. Вестгейта та інших.

Переважна кількість досліджень присвячена опису компонентів педагогічного спілкування, або розглядає його фрагментарно в процесі формування методичної складової професійної компетентності вихователів 3 правом викладання англійської мови.

Нашою метою $є$ висвітлення шляхів підготовки вихователів 3 правом викладання англійської мови до реалізації педагогічного спілкування в роботі з дітьми дошкільного віку під час їх професійного навчання у вищому навчальному закладі (ВН3).

Педагогічне спілкування, як «система органічної соціальнопсихологічної взаємодії педагога та вихованців, змістом якої $є$ обмін інформацією, здійснення виховного впливу, організація взаємин за допомогою комунікативних засобів» [2, с. 136] на заняттях англійської мови здійснюється завдяки використанню іншомовних комунікативних засобів. Тобто, кожна навчальна, виховна взаємодія потребує конкретного іншомовного забезпечення з урахуванням ï̈ спрямованості та конкретної педагогічної ситуації.

Особливостями педагогічного спілкування під час організації навчання АМ є: цільовий, навчально-комунікативний характер, різноманітність ситуацій спілкування, максимальне включення дошкільників в ігрову комунікативну взаємодію з вихователем та іншими дітьми.

Головним компонентом педагогічного спілкування $є$ іншомовне дидактичне мовлення вихователя, яке має служити: засобом створення іншомовного середовища; засобом ознайомлення із звуковим образом іноземної мови; еталоном для формування якісних навичок іншомовної вимови; засобом створення психологічно-сприятливого клімату на занятті АМ; засобом регуляції мовленнєвої та немовленнєвої поведінки дошкільників [3, с.48].

Студенти мають володіти всім спектром функцій дидактичного мовлення.

Отже, підготовка майбутніх вихователів до реалізації педагогічного спілкування, розвиток вмінь дидактичного мовлення має бути предметом їх загальної професійної підготовки у ВНЗ. 
Аналіз концептуальних підходів до організації професійної освіти вчителів свідчить про те, що найбільшої актуальності набувають: компетентнісний, контекстний та особистісно орієнтований підходи до навчання спеціалістів. Розглянемо використання зазначених підходів до предмету нашого дослідження.

Компетентністний підхід, який орієнтує весь процес педагогічної освіти на формування професійної компетентності майбутнього вихователя, спрямовує на розгляд підготовки до реалізації педагогічного спілкування, як невід'ємної складової його лінгвометодичної компетентності, формування та розвиток якої має відбуватись під час вивчення студентами різних блоків дисциплін, зокрема філологічних та методичних. Під час занять 3 практики англійської мови студенти набувають необхідний для здійснення професійної діяльності рівень володіння АМ. На заняттях з методики студенти формують комунікативно-мовленнєвий репертуар, необхідний для організації процесу навчання в ЗДО, укладають методичне портфоліо, окремі сторінки присвячуючи іншомовним фразам, виразам, які дозволяють ефективно проводити всі методичні етапи занять англійської мови.

Останнім часом у практиці вищої школи набуває поширення контекстний підхід, згідно якого набуття студентами декларативних та процедурних знань здійснюється під час діяльності академічного типу, квазіпрофесійної діяльності, навчально-професійної діяльності [1, с. 35].

У процесі підготовки студентів до педагогічного спілкування доцільності набуває використання інформаційних включень в контекст лекційних занять 3 методики навчання АМ, які містять необхідну інформацію стосовно важливих аспектів педагогічного спілкування та відбуваються у форматі міні-лекцій різних видів: лекцій-бесід, лекційдискусій, лекцій-мозкових штурмів.

Квазіпрофесійна діяльність реалізується на практичних заняттях 3 методики навчання АМ в ЗДО, шляхом мікровикладання під час якого акценти ставляться як на методичних моментах так і на особливостях складу мовлення вихователя. Аналіз ситуацій реального спілкування на заняттях АМ, моделювання ситуацій професійно-комунікативного змісту також $\epsilon$ ефективними формами підготовки майбутніх вихователів до здійснення іншомовного педагогічного спілкування.

Навчально-професійна діяльність студентів актуалізується під час проходження педагогічної практики, яка надає можливість перевірити власний рівень володіння дидактичним мовленням, адаптаційними та іншими групами комунікативних вмінь. 
Особистісно орієнтований підхід орієнтує на розгляд студента як суб'єкта власного професійного становлення, зумовлює запровадження індивідуалізованих методів навчання в процес підготовки до педагогічного спілкування.. Особистісній орієнтації досліджуваної підготовки сприяє проведення студентами мікродосліджень на основі індивідуально визначених проблем щодо ефективної реалізації педагогічного спілкування, формалізація результатів досліджень у вигляді статей, проведення курсових досліджень відповідної тематики, участь у роботі проблемних груп.

Висновком із зазначеного $є$ важливість розгляду підготовки до педагогічного спілкування майбутніх вихователів 3 правом викладання англійської мови як невід'ємної та вагомої складової їх професійного навчання у ВНЗ, яка набуває ефективності за умови реалізації компетентнісного, контекстного, особистісно орієнтованого підходів.

Перспективою подальших досліджень $€$ розгляд зазначеної підготовки з позицій технологічного підходу.

\section{Література:}

1. Вербицкий А.А. Концепция знаково-контекстного обучения в вузе / А.А. Вербицкий // Вопросы психологии. - 1987. - № 5. - С. 31-35.

2. Кан-Калик В.А. Учителеві про педагогічне спілкування / В.А. Кан-Калик // Педагогічна майстерність: хрестоматія: [навч. посіб./ упор.: І.Ф. Зязюн, Н.Б. Базилевич та ін.]. - К.: СПД Богданова А.М., 2008. $-462 \mathrm{c}$.

3. Роман С. В. Дидактичне мовлення як предмет лінгвометодичної підготовки вчителя іноземної мови початкової школи (на матеріалі англійської мови) / С. В. Роман // Іноземні мови. - 2009. - № 1. - С. 48-52. 